\title{
A Simple and Efficient Genomic DNA Extraction Protocol for Dried Leaf of Threatened Species Commiphora wightii (Arnott) Bhandari for Genetic Analysis of Plant Biological System
}

\author{
Sajjan Kumar Pooniya ${ }^{1}$, Keerti Tantwai ${ }^{1}$, Niraj Triphati ${ }^{1}$ and Sharad Tiwari ${ }^{1,2}$ \\ ${ }^{1}$ Biotechnology Centre, ${ }^{2}$ Department of Plant Breeding and Genetics, Jawaharlal Nehru \\ Krishi Vishwa Vidyalaya, Jabalpur, Madhya Pradesh, 482004, India
}

*Corresponding author

\begin{abstract}
A B S T R A C T
Keywords

Commiphora wightii (Arnott) Bhandari contains secondary metabolites,

Commiphora

wightii, Molecular

markers, PCR

amplification,

polyvinyl

pyrrolidone, $B-$

mercaptoethanol,

DNA extraction polysaccharides and phenolic compounds. The presence of secondary metabolites, reduce the yield and quality of the DNA. In the present study an alternative protocol for genomic DNA extraction from dry plant leaves was developed that is acquiescent to PCR-based genomic studies. Existing protocols were lengthy, costly or not appropriate for genomic DNA extraction from dry leaves. This modified CTAB (3\%) and PVP (Polyvinylpyrrolidone) $1.5 \%$ protocol include the use of $0.5 \mathrm{M} \mathrm{NaCl}, 0.3 \%$ B-mercaptoethanol in the extraction as well as application of autoclaved sand for proper grinding of dried leaves and inclusion of RNase A treatment in the protocol to fasten the process. The extracted DNA using present optimized protocol was super in quality and quantity. It was also suitable for polymerase chain reaction with random decamer, inter simple sequence repeat and barcode primers. The developed protocol is rapid and cost efficient with high quality and sufficient quantity of DNA for downstream PCR-based genetic analysis.

Accepted:

12 February 2019

Available Online:

10 March 2019

\section{Introduction}

Presence of secondary metabolites in plants interferes with extraction of good quality DNA for subsequent PCR based genetic analysis (Kotchoni et al., 2011). DNA extraction protocols must be standardized for every plant species with higher level of these metabolites to simplify genetic analysis of plant biological system. Various expensive

DNA extraction protocols are available with lengthy procedure. Generally the available DNA extraction protocols recommend fresh leaf samples for isolation of genomic DNA, but it is unfeasible when the samples are collected from distant and rare places. These types of circumstances require the development of the protocols for extracting DNA from dried leaf samples. Guggul (Commiphora wightii) is a pharmacologically,
\end{abstract}


economically and ecologically important species that grows wild in state of Madhya Pradesh, Gujarat and Rajasthan in India. Generally guggul plants are found in arid and semi arid climate and shown tolerance to poor soil in Rajasthan. The plant contains essential oils, mainly myresene, dimyrecene and polymyrecene, Z-guggulosterone, Eguggulosterone. The presence of phytochemicals like steroid, saponins, tannins, flavanoids, and alkaloids has also been confirmed (Zaid et al., 2015). Considering the above issues we have made substantial modifications to make the CTAB based DNA extraction protocol (Saghai-Maroof et al., 1984) more reliable, fast and economical. This modified protocol is also able to give good yield with small samples of plant tissues. Moreover, obtained DNA would be of good quality suitable for molecular analysis.

\section{Materials and Methods}

\section{Source of biological material}

Leaf samples were obtained from Commiphora wightii plants from different locations of India (Table 1) and stored for genomic DNA isolation.

\section{Chemicals, reagents and solutions}

(i) DNA Extraction: $100 \mathrm{mM}$ Tris- $\mathrm{HCl}$ (pH 8.0), 20mM EDTA (pH8.0), 0.5M NaCl, 3\% CTAB (Cetyl Trimethyl-Ammonium Bromide), $0.3 \% \quad \beta$-mercaptoethanol, $1.5 \%$ PVP (Polyvinylpyrrolidone), 24:1Chloroformisoamyl alcohol (IAA), 3M sodium acetate (pH4.8), Isopropanol $\left(4^{\circ} \mathrm{C}\right), 70 \%$ ethanol.

(ii) PCR amplification and electrophoresis: 10X PCR buffer (1X working), $2.5 \mathrm{mM}$ $\mathrm{MgCl}_{2}, 10 \mathrm{mM}$ dNTPs $(200 \mu \mathrm{M}), 10 \mathrm{pM}$ Primer (RAPD and ISSR), Taq DNA Polymerase (5 Unit/ $\mu 1)$, 50ng template DNA, Nuclease free $\mathrm{H}_{2} \mathrm{O}$ for volume making, Agarose, 1X TAE, Ethidium bromide, primers, DNA ladder.

\section{Preparation of DNA extraction buffer}

The DNA extraction buffer was used for the homogenization of chemical $100 \mathrm{mM}$ Tris (pH, 8.0), $0.5 \mathrm{M} \mathrm{NaCl}, 20 \mathrm{mM}$ EDTA (8.0 $\mathrm{pH})$. After adding 3\% CTAB and 1.5\% PVP the final volume was made up $100 \mathrm{ml}$ with nuclease free water. $\beta$-mercaptoethanol was added just prior to keeping DNA extraction buffer in water bath for incubation at $65^{\circ} \mathrm{C}$.

\section{Genomic DNA isolation}

$2 \mathrm{~g}$ of fresh and healthy leaves were taken for genomic DNA isolation.

Leaf sample was homogenized in liquid nitrogen using a pestle and mortar and grind with liquid nitrogen in the presence of autoclaved sand to make fine powder.

The fine powder was transferred to $50 \mathrm{ml}$ oakridge tube and $10 \mathrm{ml}$ of DNA extraction buffer (preheated at $65^{\circ} \mathrm{C}$ ) was added and mixed thoroughly. Sample tubes were incubated at $65^{\circ} \mathrm{C}$ in water bath for $1 \mathrm{~h}$, with intermittent mixing after $10 \mathrm{~min}$ during incubation.

$10 \mu \mathrm{l}$ RNase A (20mg/ml) was added and mixed gently. Sample tubes were incubated at $37^{\circ} \mathrm{C}$ for $40 \mathrm{~min}$.

Equal volume of Chloroform: Isoamyl alcohol (24: 1) was added and mixed gently and tubes were centrifuged at $12,000 \mathrm{rpm}$ for $12 \mathrm{~min}$ at room temperature. Supernatant was transferred to a fresh $50 \mathrm{ml}$ oakridge tube and equal volume of chloroform: isoamyl-alcohol (24:1) was added again and mixed gently.

The mixture was centrifuged again at 10,000 rpm for $10 \mathrm{~min}$ at room temperature.

The supernatant was transferred to a fresh 50 $\mathrm{ml}$ tube and an equal volume of pre-chilled isopropanol was added and mixed gently by 
inverting and kept for $10 \mathrm{~min}$ at room temperature without disturbing.

The precipitated DNA was then spool out using $1.2 \mathrm{ml}$ cut tips and transferred to a 1.5 $\mathrm{ml}$ microcetrifuge tube.

DNA was pelleted by spinning at $10,000 \mathrm{rpm}$ for $8 \mathrm{~min}$. Supernatant was discarded and pellet was washed twice with $500 \mu \mathrm{l}$ of $70 \%$ ethanol.

The pellet was dried up at room temperature and dissolved in $100 \mu 1$ Tris: EDTA buffer and stored at $-20{ }^{\circ} \mathrm{C}$ for further use.

\section{Testing of DNA quality and purity}

Purity of DNA was checked by taking the ratio of Optical Density (O.D.) using Nanodrop-Spectrophotometer at 260nm to $280 \mathrm{~nm}$. The qualities of extracted DNA were tested by gel electrophoresis. It was done on $0.8 \%$ agarose gel stained with Ethidium Bromide samples and amplified fragments of DNA were observed in gel documentation system.

\section{Amplification of DNA using primers}

The PCR amplification procedure for amplification of DNA RAPD was followed as per protocol described by Williams et al (1990). The components and their concentration used in the RAPD and ISSR PCR reaction were prepared as follows: PCR amplification reactions volume $20 \mu \mathrm{l}$ consisting $2 \mu \mathrm{l}$ of PCR buffer, $2.4 \mu \mathrm{l}$ of $\mathrm{MgCl}_{2}$, $0.2 \mu \mathrm{l}$ of $\mathrm{Taq}$ Polymerase (5 Unit/ $\mu \mathrm{l}$ ), $0.5 \mu \mathrm{l}$ of dNTPs, $2 \mu \mathrm{l}$ of Primer, $2 \mu \mathrm{l}$ of genomic DNA and nuclease free water to makeup the total volume. For DNA barcode primers ( $r b c \mathrm{~L}$ and $m a t \mathrm{~K})$ the components were used as follows: $1 \mu \mathrm{l}$ of PCR buffer, $0.7 \mu \mathrm{l}$ of $\mathrm{MgCl}_{2}, 0.1 \mu \mathrm{l}$ of Taq Polymerase (5 Unit/ $\mu \mathrm{l}$ ), $0.2 \mu \mathrm{l}$ of dNTPs, $0.5 \mu \mathrm{l}$ of forward primer, $0.5 \mu \mathrm{l}$ of reverse primer, $1 \mu \mathrm{l}$ of genomic DNA and nuclease free water to makeup the total volume $10 \mu \mathrm{l}$. Amplifications were performed using "BIORAD T100 and Agilent Technologies Sure Cycler 8800" programmable thermal cycler with the cycling parameters that was programmed for ISSR an initial denaturation step at $94^{\circ} \mathrm{C}$ for $4 \mathrm{~min}$ followed by 45 cycles at $94^{\circ} \mathrm{C}$ for 45 second, $50^{\circ} \mathrm{C}$ for $1 \mathrm{~min}$ annealing and $72^{\circ} \mathrm{C}$ for 2 min elongation. In the final cycle, the elongation step at $72^{\circ} \mathrm{C}$ was extended by $5 \mathrm{~min}$. Likewise; the temperature profile used in RAPD PCR amplification were the same except the annealing temperature was $37^{\circ} \mathrm{C}$. The cycling parameters that was programmed for $r b c \mathrm{~L}$ and matK primers were: an initial denaturation step at $94^{\circ} \mathrm{C}$ for $3 \mathrm{~min}$ followed by 35 cycles at $94^{\circ} \mathrm{C}$ for 30 second, annealing for $r b c \mathrm{~L}$ at $55^{\circ} \mathrm{C}$ and for $m a t \mathrm{~K}$ at $58^{\circ} \mathrm{C}$ for $30 \mathrm{sec}$ and $72^{\circ} \mathrm{C}$ for $45 \mathrm{sec}$ elongation. In the final cycle, the elongation step at $72^{\circ} \mathrm{C}$ was extended by 7 $\min$.

\section{Results and Discussion}

Extraction of superior quality DNA from Commiphora wightii is tedious task due to existence of various secondary metabolites, polysaccharides and phenolic compounds. During present study the genomic DNA was isolated from dried leaf samples of four $C$. wightii genotypes. This procedure is applicable to fresh and old leaves of $C$. wightii. This protocol includes the application of $3 \%$ of CTAB and $1.5 \%$ PVP in the DNA extraction buffer. The use of CTAB in the DNA extraction buffer as it facilitates to disrupt the cell membrane (Bressan et al., 2014). Polyvinylpyrrolidone (PVP) is an essential agent to eliminate the polyphenols by forming intricate hydrogen bonding with polyphenols and proficiently detach it from DNA (Kit and Chandran 2010). Autoclaved sand was used during grinding process to convert leaves into fine powder. Without sand 
it was difficult to crush the leaves properly. The extraction and purification of DNA was performed in a single protocol. Good quality DNA obtained using the protocol (Table 1, Fig. 1). Obtained DNA was quantified using nanodrop-spectrophotometer.

DNA concentration was ranged from 27.48 to 40.83 $\mu \mathrm{g} / \mu \mathrm{l}$ and optical density (OD) was between 1.70 and 1.81.This method solved the problems of DNA degradation, contamination, and low yield due to binding and coprecipitation with starch and polysaccharides. The isolated DNA proved amenable to PCR amplification (Fig. 2). The technique is fast, reproducible, and can be applied for amplification of RAPD, ISSR and other molecular markers. The optimized DNA extraction buffer composed of higher quantity of $\mathrm{CTAB}$ as it makes complex with polysaccharides and fructans (Gawel and
Jarret 1991). Whereas other chemical PVP forms insoluble compounds with lactones and phenolics (Kim et al., 1997). All these compounds are detached by precipitation for the duration of centrifugation after mixing with chloroform: isoamyl alcohol. Raising the quantity of $\beta$-mercaptoethanol from 0.2 to $0.3 \%$ helped to ensure the oxidation of phenolic compounds. Insertion of phenol in the protocol was avoided during application of chloroform: isoamyl alcohol solution to obtain high molecular weight DNA, as phenol might break phosphodiester bonds in DNA causing its degradation. A separate RNase A application, as recommended in numerous published protocols was incorporated in our extraction protocol and additional two times application of chloroform: isoamyl-alcohol (24:1) combination was competent to eliminate all impurities.

Table.1 Concentration and Optical Density of DNA isolated from dried leaves of C. wightii

\begin{tabular}{|c|l|l|l|l|c|}
\hline S. & Label & Place of collection & $\begin{array}{l}\text { Age of plant } \\
\text { (years) }\end{array}$ & $\begin{array}{l}\text { Concentration } \\
(\boldsymbol{\mu g} / \boldsymbol{\mu l})\end{array}$ & OD \\
\hline $\mathbf{1 .}$ & CW1 & Morena & 12 & 32.59 & 1.70 \\
\hline $\mathbf{2 .}$ & CW2 & Morena & 12 & 40.83 & 1.74 \\
\hline $\mathbf{3 .}$ & CW3 & CAZRI, Jodhpur & 8 & 31.58 & 1.73 \\
\hline $\mathbf{4 .}$ & CW4 & AAU, Anand & 9 & 27.48 & 1.81 \\
\hline
\end{tabular}

Fig.1

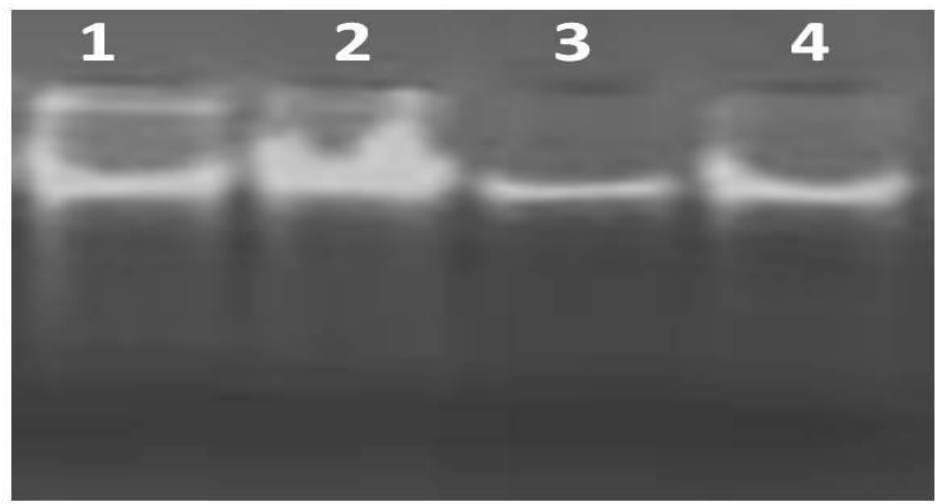

Fig. 1 DNA from dried leaf samples of Commiphora wightii 
Fig.2

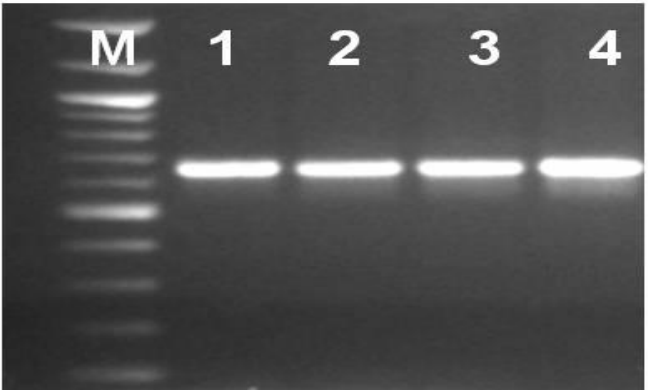

A. $r b c L$

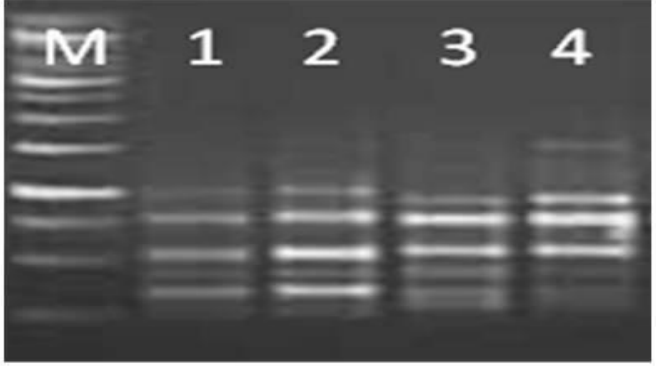

C. OPH-4

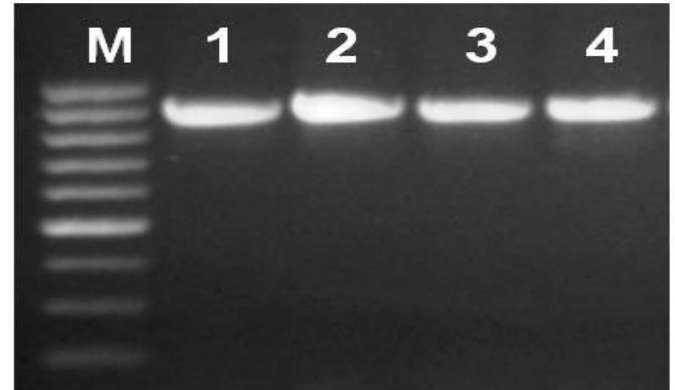

\section{B. matK}

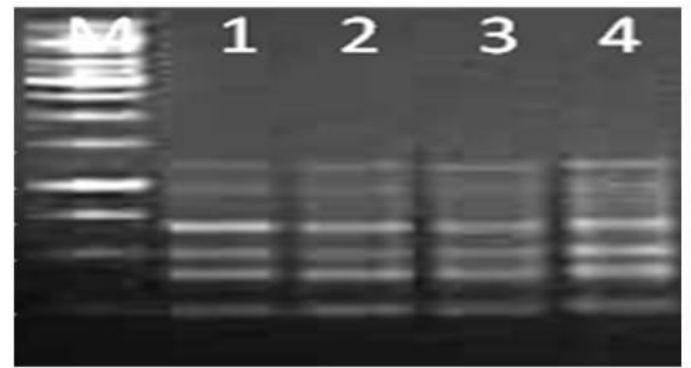

D. UBC-807

\section{Fig. 2 Amplification pattern of Commiphora wightii DNA isolated from dried leaves}

Application of sodium acetate removes the majority of secondary metabolites and polysaccharides from the DNA consequential in improved yield of high molecular weight of DNA. The DNA extracted by this protocol was used in the polymerase chain reaction with $r b c \mathrm{~L}, m a t \mathrm{~K}$, and ISSR and RAPD primers (Fig. 2). It was found that the PCR amplicons from successful reactions showed good quality bands with all primers. It indicates that the DNA extracted using this method was free from different secondary metabolites e.g. flavonoids, terpenes, and phenolic compounds, which hinder with the quality and yield of the DNA (Porebski et al., 1997). It means secondary metabolites were effectively removed for the duration of the extraction procedure. Therefore, it confirms that the extracted DNA was appropriate for any analysis make use of PCR as a technique. The extracted DNA demonstrated acquiescent to PCR amplification. The developed protocol is rapid and reproducible, producing good quality DNA for amplification of molecular markers.

Furthermore, we observed that the method detailed in this paper is efficient for plants that were recalcitrant to isolate the DNA. Finally, we trust that this protocol will be cooperative for DNA based molecular studies of various wild plant species with high level of secondary metabolites. On the basis of the results, it can be concluded that the present protocol gives genomic DNA with good quality and intactness; a spectrophotometric $\mathrm{A}_{260} / \mathrm{A}_{280}$ value $>1.81$. Furthermore, the protocol can be applied to extract DNA from young plant leaves as well as dried or frozen tissues. It is appropriate in situations when liquid nitrogen does not exist. The present protocol may also be used to other medicinal plants rich in polyphenolic compounds and polysaccharides. 


\section{References}

Bressan, E. A., Rossi, M. L., Gerald, L. T. and Figueira, A. 2014. Extraction of high quality DNA from ethanolpreserved tropical plant tissues. BMC Research Notes, 268.

Gawel, N. J. and Jarret, R. L. 1991. A modified CTAB DNA extraction procedure for Musa and Ipomoea. Plant Molecular Biology Reporter, 262-266.

Kim, C.S., Lee, C. H., Shin, J. S., Chung, Y.S. and Hyung, N. I. 1997. A simple and rapid method of isolation of high quality genomic DNA from fruit trees and conifers using PVP. Nucleic Acids Research, 1085-1086.

Kit, Y.S. and Chandran, S. 2010. A Simple, rapid and efficient method of isolating DNA from Chokanan mango (Mangifera indica L). African journal of biotechnology, 5805-5808.

Kotchoni, S. O., Gachomo, E. W. JimenezLopez, J. C. 2011. A plant cocktail amenable for PCR-based genetic analysis in Arabidopsis thaliana. Molecular Biology Reports, 5281-5285. Porebski, S. Bailey, L. G. Baum, B. R. 1997. Modification of a CTAB DNA extraction protocol for plants containing high polysaccharide and polyphenol components. Plant Molecular Biology Report, 8-15.

Saghai-Maroof, M. A. Soliman, K. M. Jorgensen, R. A. Allard R. W. 1984. Ribosomal DNA sepacer-length polymorphism in barley: mendelian inheritance, chromosomal location, and population dynamics. Proceeding of the National Academy of Science, 8014,

Zaid, A. Bhardwaj, M. Kumar A. 2015. Phytochemical Analysis and Antimicrobial Activity of Commiphora wightii Plant (Guggul) Extract. Research Journal of Pharmaceutical, Biological and Chemical Sciences, 2125.

\section{How to cite this article:}

Sajjan Kumar Pooniya, Keerti Tantwai, Niraj Triphati and Sharad Tiwari. 2019. A Simple and Efficient Genomic DNA Extraction Protocol for Dried Leaf of Threatened Species Commiphora wightii (Arnott) Bhandari for Genetic Analysis of Plant Biological System. Int.J.Curr.Microbiol.App.Sci. 8(03): 1619-1624. doi: https://doi.org/10.20546/ijcmas.2019.803.188 